\title{
HUBUNGAN TIMBAL BALIK ANTARGENERASI MELALUI RUANG PUBLIK UNTUK BERINTERAKSI SOSIAL DAN BERMAIN
}

\author{
Renadi Mohammad Rediansyah'1), Petrus Rudi Kasimun²) \\ ${ }^{1)}$ Program Studi S1 Arsitektur, Fakultas Teknik, Universitas Tarumanagara, rreji1202@gmail.com \\ 2)Program Studi S1 Arsitektur, Fakultas Teknik, Universitas Tarumanagara, rudi.kasimun@gmail.com
}

\begin{abstract}
Abstrak
Bermain merupakan aktivitas yang dapat meningkatkan kualitas hidup manusia. Meningkatkan keaktifan sel saraf motorik dan sensorik pada otak merupakan dampak positif dari bermain. Semua segmen umur membutuhkan aktivitas bermain mulai dari anak-anak sampai lanjut usia. Setiap segmen umur memiliki minat dan kemampuan sosial yang berbeda. Oleh karena itu setiap segmen umur memiliki tempat bermain masingmasing. Seiring dengan bertambahnya umur tempat bermain akan berubah wujudnya sesuai dengan minat. Cipete Selatan merupakan kelurahan yang didominasi oleh hunian dan komersil. Ada peluang untuk menciptakan tempat bermain untuk semua segmen umur. Fasilitas ini akan memiliki tempat bermain untuk setiap segmen umur secara terpisah dan bersama. Dipisahkan agar setiap segmen umur dapat berinteraksi dengan segmen umur masing-masing sesuai dengan kemampuan sosialnya. Digabungkan agar tiap segmen umur akan memberikan hubungan untuk saling belajar, yang muda belajar dari yang tua, yang tua belajar dari yang muda. Fasilitas ini akan diisi dengan program yang positif seperti olahraga, tempat bermain, dan tempat berbincang agar anak-anak dan remaja dapat mengasah, dewasa mengembangkan, dan lanjut usia menuangkan minat dan kemampuan sosialnya. Sehingga tercipta suatu hubungan timbal balik antargenerasi. Dengan ini diharapkan Kelurahan Cipete Selatan memiliki fasilitas sosial yang dapat meningkatkan kualitas hidup masyarakatnya.
\end{abstract}

Kata Kunci: Belajar; Bermain; Fasilitas; Hubungan; Umur

\begin{abstract}
Play is an activity that can improve the quality of life. Increasing motoric and sensoric neuron activity are one of the positivity by playing. Play is an activity needed by children to elderly. All of the segmented age grop have their interest and different social skill level. Therefore, each age group have their own play space. As they got older, play space will changes by their interest. South Cipete is a district dominated by housing and commercial. There are oppurtunity to create play space for all ages. This facility will have play space for every group age and for all ages. Every group have their own play space to interact with their group ages according to their social skill ability. Play space is combined from all of the group ages to create mutual relation, younger group of ages can learn from older group of age and older group of ages can learn from younger group of ages. This facility will provide positive programme like sports, play space, and a place to interact so that childrens and teens can learn, adults can hone, and elderly can pour their interests and social skill. So as to create a reciprocal intergenerational realtionship. With this, it is hoped that South Cipete has social facilities that can improve the quality of life of its people.
\end{abstract}

Keywords: Age; Facility; Learn; Play; Relationship 


\section{PENDAHULUAN}

\section{Latar Belakang}

Bermain merupakan aktivitas yang dilakukan sehari-hari oleh manusia. Efek dari bermain terbukti memberikan dampak positif. Bermain dapat menghilangkan penat, juga melatih sel saraf motorik dan sensorik pada otak. Permainan juga dapat memperluas koneksi dan melatih kemampuan bersosialisasi khususnya pada permainan kelompok. Manfaat bermain memberikan dampak yang baik pada manusia. Fasilitas yang bersifat inklusif dapat disebut sebagai ruang publik. Hubungan timbal balik antargenerasi dapat dibentuk dengan menggabungkan kombinasi program bermain dan sosialisasi. Bermain dibagi dengan segmen umur lalu dipertemukan pada 'ruang bersama' untuk sosialisasi. Sehingga tercipta suasana timbal balik, yang muda belajar dari yang tua, yang tua belajar dari yang muda sehingga nilai kehidupan terus meningkat. Bermain dapat meningkatkan kualitas hidup manusia. Menciptakan perencanaan ruang publik inklusif sehingga terjadi hubungan timbal balik antargenerasi yang positif. Ruang publik dapat menjadi katalis penggunanya untuk bermain dan bersosialisasi.

\section{Rumusan Masalah}

Dominasi fungsi hunian pada tapak menunjukan kurangnya ruang publik untuk fasilitas sosial di Cipete Selatan. Padahal, peran ruang publik sebagai wadah aktivitas sosial dalam bermasyarakat sangat besar dalam mendefinisikan karakter dari suatu kota. Dengan adanya ruang publik, masyarakat dapat melakukan aktivitas sosial dan menghabiskan waktu luang yang membentuk karakter dan kualitas hidup Cipete Selatan. Kondisi tapak yang berada di antara perumahan kaum menengah keatas dan perkampungan kota menunjukan adanya kesenjangan sosial. Pada kenyataannya kesenjangan sosial seperti dinding yang memisahkan 2 golongan, padahal tinggal di wilayah yang sama. Kesenjangan sosial terjadi karena perbedaan kelas ekonomi dan dapat dihilangkan melalui program-program yang menggabungkan kedua golongan seperti bemain dan berkomunikasi.

\section{Tujuan}

Ruang publik dapat menjadi jawaban di Cipete Selatan. Memaksimalkan potensi tapak sebagai titik temu masyarakat kaum menengah atas dan perkampungan kota. Interaksi sosial akan menghapuskan kesenjangan sosial. Aktivitas sosial yang dikemas dengan bermain diharapkan dapat membentuk karakter dan meningkatkan kualitas hidup Masyarakat Cipete Selatan. Ruang bermain dikelompokan berdasarkan segmen umur. Setiap segmen umur memiliki tingkat kemampuan bersosialisasi yang berbeda. Bagi anak-anak dan remaja dapat mengasah, dewasa mengembangkan, dan lanjut usia menuangkan minat dan kemampuan sosialnya. Hasil dari ruang bermain akan berdampak pada perilaku dan tata krama dalam bermasyakarat. Hubungan timbal balik antargenerasi merupakan suasana yang ingin diciptakan. Interaksi sosial antargenerasi saling memberikan manfaat. Yang muda dapat belajar untuk melatih komunikasi, melatih daya nalar, dan berbagi budaya dan tradisi. Sebaliknya yang tua dapat memberikan semangat, pengalaman, dan memiliki kesempatan untuk bernostalgia.



Gambar 1. Ilustrasi Hubungan Timbal Balik Antargenerasi 


\section{KAJIAN LITERATUR}

\section{Open Architecture}

Open architecture memiliki arti arsitektur terbuka. Kata dasar terbuka adalah buka. Secara bahasa buka memiliki arti sebagai antara (Badan Pengembangan dan Pembinaan Bahasa, 2016). Kondisi terbuka terjadi diantara bidang besar dan tembus. Terbuka dalam Open Architecture memiliki arti tanpa memandang kelas ekonomi, kelas sosial, terbuka untuk siapa saja. Tidak eksklusivitas, melainkan inklusif yang memiliki kaitan dengan Third Place. Arsitektur sekarang memiliki Fluid Programme. Open Architecture dapat menjadi identitas suatu tempat yang dibutuhkan oleh warga yang memiliki program multifungsi (Sutanto, 2020). Tempat inklusif dapat menjadi fasilitas umum atau ruang publik. Masyarakat dapat menggunakannya tanpa biaya dan tidak dibatasi oleh waktu.

\section{Third Place}

Third Place secara bahasa memiliki arti tempat ketiga. Secara harafiah tempat ketiga ini adalah destinasi ketiga dalam memenuhi kebutuhan beraktivitas. Tempat pertama adalah tempat memulai aktivitas yaitu rumah (primer), tempat kedua adalah kantor (sekunder). Tempat ketiga adalah ruang yang dibutuhkan untuk menjalankan gaya hidup dan sosial diluar rumah dan pekerjaan (tersier). Pergerakan Third Place memiliki letak diantara rumah dan tempat bekerja. Dengan terpenuhi nya ketiga tempat ini, maka seseorang akan memiliki kehidupan yang seimbang. Tempat ketiga adalah tempat untuk memenuhi kebutuhan minat dan sosial. Contoh seperti bermain futsal dapat dikatakan ruang ketiga. Futsal merupakan olahraga kelompok yang dapat dilakukan sepulang kerja untuk melepas penat. Selain melepas penat, futsal juga melatih fisik dan membutuhkan stamina untuk bermain. Dari sisi sosial, bermain futsal pasti membutuhkan komunikasi dan kerjasama. Dalam Buku The Great, Good Place mengatakan karakteristik sebuah Third Place (Oldenburg, 1996), yaitu:

a. Netral

Tempat yang terbuka untuk semua orang. Tidak ada kepemilikan, tapi ada rasa saling memiliki. Terbuka kapan saja, dan mampu memberikan wadah interaksi dan aktivitas untuk masyarakat sekitar.

b. Leveler

Menciptakan lingkungan yang inklusif sehingga tidak membawa status dan jabatan. Semuanya memiliki kesamaan hak, adil, dan beradab.

c. Aktivitas Utama adalah Percakapan

Wadah untuk bertukar informasi dimana percakapan adalah aktivitas yang utama. Dengan bercakap, manusia sudah melakukan interaksi dan hubungan sosial.

d. Memiliki aksesibilitas dan akomodasi

Dapat diakses dan memberikan kebutuhan untuk menjalankan aktivitas yang dilakukan bersama.

e. Memiliki pendatang yang rutin

Fasilitas ini akan memiliki pendatang rutin untuk melakukan interaksi sosial, menjadi keseharian, mengisi kebutuhan tersier. Sehingga pengguna fasilitas yang rutin akan saling kenal.

f. Memiliki fisik yang plain dan sederhana

Untuk mendukung fungsi terbuka, maka tidak boleh memiliki fisik yang terlalu mewah atau terlalu murah karena akan menimbulkan target pemasaran untuk fasilitas umum.

g. Memiliki mood 'ceria'

Kebutuhan tersier ini harus dikemas dengan ceria, agar dapat memberikan informasi dan beraktivitas dengan baik dan bermanfaat.

Suasana nyaman

h. Memiliki aktivitas yang berbeda dengan rumah (privat) dan tempat kerja (semi-privat). Third Place memiliki fungsi public dan memberikan suasana yang menyenangkan. 
Dari Karakteristik diatas, menunjukan bahwa Third Place dan Open Architecture memiliki tujuan yang sama dalam wujud fasilitas sosial atau ruang publik. Sebagai penyeimbang gaya hidup antara hidup (live) dan kerja (work), yaitu waktu luang (leisure). Jika dikemas dengan permainan pada tiap segmen umur dan tersedia ruang bersama untuk bersosialisasi maka akan tercipta hubungan timbal balik antargenerasi.

\section{Bermain}

Bermain menurut $\mathrm{KBBI}$ adalah melakukan sesuatu untuk bersenang-senang (Badan Pengembangan dan Pembinaan Bahasa, 2016). Arti bermain sangat luas. Berdiskusi, bermain bola, bersepeda, atau aktivitas lainnya yang memberikan perasaan senang sudah masuk kategori bermain. Bermain (play) merupakan gaya hidup yang erat kaitannya dengan waktu luang (leisure). Secara spesifik bermain memiliki 16 jenis tipe (Halloran, 2018) dari Bob Hughes (lihat Hughes, 2002) terdapat 5 yang dapat diimplementasikan dalam Open Architecture dan Third Place, yaitu:

\section{a. Social Play}

Setiap interaksi sosial yang terjadi merupakan Social Play. Baik dalam permainan maupun dalam bersosialisasi diharapkan dapat mematuhi peraturan permainan dan menjaga etika dan tata krama dalam ruang sosial.

b. Exploratory Play

Menggunakan indera penciuman, sentuh, dan rasa untuk menjelajahi dan menemukan rasa dan fungsi pada ruang sekitar. Rangsangan pada indera dapat dilakukan dengan menerapkan warna, material, dan bentuk pada proyek.

c. Object Play

Objek dapat menjadi sebuah media dalam bermain. Bisa sebagai indikasi kemenangan dan kekalahan dari permainan atau menjadi objek dalam melakukan ekspresi. Contohnya adalah Permainan Sepak Bola dan Melukis.

d. Rough, Tumble Play, and Locomotor Play

Tipe Permainan ini memiliki kesamaan yaitu akan membakar energi. Permainan ini identik dengan saraf motorik yang membutuhkan pergerakan dan strategi dalam bermain. Contohnya seperti permainan Petak Umpat, Bentengan, dsb.

Dari 5 permainan ini akan terbentuk aktivitas dan program yang dapat disusun berdasarkan segmen umur dan aktivitas. Ruang bermain berbeda dengan taman bermain (playground), Play space represents mental freedom, and leeway to deviate from the rules (Lefaivre \& Doll, 2007). Taman bermain identik dengan pengguna yang spesifik, yaitu anak-anak, sedangkan ruang bermain lebih bebas dan tidak ada aturan.

\section{A Pattern Language}

Acuan untuk merancang bangunan dan perencanaan tata kota. A pattern language merupakan sebuah bahasa yang tak lekang oleh waktu untuk mendeskripsikan fungsi kota dan bangunan (Alexander, et al., 1977). Pola bahasa disini tidak sepenuhnya menjadi acuan karena setiap masyarakat yang hidup dan menyeluruh (komunitas) memiliki keunikan dan perbedaan pola bahasa masing-masing. Buku ini memberikan kategori berupa pola bahasa yang dapat digunakan sebagai acuan dalam merancang bangunan dan perencanaan tata kota. Nama $A$ Pattern Language merupakan sebuah metode untuk mengaplikasikan teori dalam buku tersebut. Sebagai contoh puisi adalah rangkaian sebuah kata dari sebuah bahasa. Begitu juga dengan Pattern Language dapat dirangkai menjadi suatu rancangan bangunan dan perencanaan kota. Buku ini membantu menyusun bayangan rancangan desain.

A Pattern Language disusun secara luas menuju spesifik dalam merancang bangunan dan perencanaan tata kota. Terdapat 253 pola yang dapat dijadikan acuan. Rangkaian pola pilihan 
yang digabung mampu dijadikan gambaran desain menuju tahap gambar. Metode merangkai pola menjadi sebuah rancangan untuk bangunan dan perencanaan tata ruang dalam tugas ini yaitu merancang ruang publik. Berikut adalah rangkaian pola yang menjadi acuan dalam merancang yaitu:

\section{a. Neighbourhood Boundary}

Tapak berada diantara perumahan kota menengah atas dan perkampungan kota. Terlihat adanya sebuah kesenjangan sosial. Sekitaran tapak harus memiliki sebuah tempat untuk mengadakan pertemuan publik, dimana publik dapat melebur (Alexander, et al., 1977). Tujuannya adalah mempersatukan dengan melakukan interaksi sosial.

b. Old People Everywhere

Hubungan timbal balik antargenerasi membutuhkan semua segmen usia, salah satunya adalah usia lanjut. Usia lanjut saling membutuhkan sesama usia lanjut, tetapi mereka juga membutuhkan segmen umur dewasa, remaja, dan anak-anak untuk berinteraksi (Alexander, et al., 1977). Diperlukannya ruang untuk usia lanjut untuk berinteraksi dan ruang untuk berinteraksi bersama segmen umur lainnya, seperti ruang bersama. Ruang bersama ini memiliki peran yang besar untuk menghadirkan suasana hubungan timbal balik antargenerasi.

c. Connected Play

Sama seperti usia lanjut, anak-anak saling membutuhkan. Jika anak-anak tidak bermain dengan anak-anak lainnya selama usia 5 tahun pertama (balita) ada kemungkinan besar mereka akan mengalami gangguan kejiwaan dalam hidupnya (Alexander, et al., 1977). Fase ini merupakan perkenalan anak pada ruang sosial bersama anak seumurannya atau dalam satu segmen umur. Pentingnya ruang bermain berdasarkan segmen umur dan ruang bersama untuk berinteraksi agar terciptanya suasana timbal balik.

d. Local Sports

Olahraga memiliki peran yang signifikan khususnya olahraga kelompok (tim). Ruang publik yang memiliki fasilitas olahraga yang digemari otomatis akan meningkatkan kualitas hidup masyarakatnya melalui berolahraga dan kompetisi. Poin ini harus diimplementasikan dengan spesial, dengan menerapkan akses yang mudah, menarik perhatian masyarakat, adanya fasilitas seperti tribun, toilet, dan ruang ganti (Alexander, et al., 1977). Strategi tersebut diharapkan mampu untuk menarik masyarakat untuk ikut berolahraga agar tercipatanya sebuah interaksi atau kerjasama tim.

e. Adventure Playground

Usia muda adalah usia yang sangat aktif. Menciptakan suasana permainan salah satunya menempatkan massa bangunan dengan rongga ruang terbuka. Permainan merupakan jalan yang ditempuh untuk menjadi dewasa, menghilangkan ketegangan dan eksplorasi masa depan (Alexander, et al., 1977). Ruang tersebut akan memberikan perluasan pada ruang bermain anak sehingga keaktifan anak akan dipenuhi untuk bermain dan berkesplorasi.

f. Positive Outdoorspace

Ruang luar memiliki 2 karakteristik, yaitu ruang luar positif dan negatif. Ruang luar negatif adalah ruang luar yang tidak dibentuk atau ruang sisa, Sebaliknya ruang luar positif adalah ruang yang dibentuk dan direncanakan (Alexander, et al., 1977). Percobaan merancang ruang luar dengan menentukan letak massa bangunan, vegetasi, dan jalan setapak sehingga tercipta ruang luar yang positif pada proyek ini.

g. Sequence of sitting space

Ruang ketiga memiliki program utama yaitu interaksi sosial. Setiap sudut bangunan memiliki potensi untuk dijadikan tempat duduk (Alexander, et al., 1977). Penempatan ruang duduk di ruang publik bisa dimana saja seperti di sudut massa bangunan, ruang pada massa bangunan, dan atap bangunan. Dengan banyaknya ruang duduk diharapkan dapat menjadi ruang publik yang dapat meningkatkan interaksi sosial. 


\section{Genius Loci}

Spirit of Place atau roh suatu tempat dijelaskan dalam Buku Genius Loci. Buku ini membahas tentang suasana sebuah tempat. Tentang keberadaan sebuah tempat dan karakternya. Memberikan penjelasan tentang merancang sebuah tempat. Tempat adalah latar dari kehidupan. Tanpa informasi tempat, maka suatu informasi tidak menjadi spesifik. Tempat memiliki jiwa, terdiri dari material, substansi, bentuk, tekstur, dan warna menciptakan suatu suasana yang menjadi esensi sebuah tempat. Seperti istilah guna dan citra, tempat memiliki fungsi dan juga citra yang membentuk jiwa suatu tempat. Struktur sebuah tempat memiliki perbedaan antara alam dan ciptaan manusia. Alam merupakan ciptaan Tuhan untuk makhluknya hidup di dunia. Ciptaan manusia merupakan karya dari manusia dengan tujuan untuk bertahan hidup. Representasi langit-bumi sering di intepretasikan sebagai hubungan antara Tuhan dengan manusia, dimana vertikalisme untuk Tuhan dan horizontalisme untuk sesama manusia. Dengan adanya vertikalisme dan horizontalisme menciptakan suatu eksistensi dimensi.

Eksistensi suatu tempat yang membentuk dunia. Martin Heidegger mengatakan bahwa "The Thing Things World" yang memiliki arti bahwa suatu benda akan membentuk dunia pada buku Genius Loci (Schulz, 1976). Ketika Britania Raya memiliki Tugu Stonehenge, Italia memiliki Menara Pisa, tempat inilah yang mengisi eksistensi tempat. Setiap bagian di dunia memiliki tempat dan karakter masing-masing. Karakter sangat bergantung pada caranya ia terbentuk, menjadi terlihat ketika memiliki output (bangunan). Fenomenologi sebuah tempat harus memiliki dasar kontruksi yang kuat antara hubungan asal muasal dan artikulasi. Dengan ini teori arsitektur mendapatkan dasar yang konkret. Kehadiran suatu arsitektur adalah untuk memberikan tapak menjadi suatu tempat, untuk menemukan arti dari potensi yang ada saat ini dalam sebuah lingkungan. Untuk merancang tempat, sangat diperlukan untuk menemukan karakter lingkungan dan apa yang dibutuhkan. Dengan ini, arsitektur dapat melahirkan jiwa dari suatu tempat dan meningkatkan kualitas hidup manusia.

\section{METODE}

\section{Metode Penelitian}

Metode yang digunakan adalah metode kualitatif. Berangkat dari data lapangan, untuk dianalisa dengan teori arsitektur dan bermain untuk merancang ruang publik. Metode ini adalah bentuk pemahaman fenomena tentang apa yang dialami oleh subjek peneliti. Hasil dari metode ini menekankan pada makna ruang bermain dan interaksi sosial. Jenis penelitian kualitatif fenomenologi untuk memperhatikan dan menelaah fokus fenomena, aspek subjektif dan perilaku bahan penelitian. Pengumpulan data dengan cara survei langsung ke tempat dan mewawancarai penduduk sekitar tapak untuk mengetahui fenomena yang ada di Kelurahan Cipete Selatan. Pengumpulan data merupakan landasan untuk menganalisa apa yang dibutuhkan masyarakat.

Memperhatikan dan menelaah fenomena yang terjadi di sekitar tapak. Program arsitektur dapat terbentuk melalui pengumpulan data dan memperhatikan perilaku dan aktivitas yang terjadi di sekitar tapak. Mencari jiwa pada tapak untuk mengetahui citra apa yang dipancarkan. Dari data dan analisa tersebut akan diterapkan teori yang dikumpulkan untuk menghasilkan arsitektur berupa ruang publik. Dengan tujuan untuk memenuhi dan meningkatkan kualitas hidup masyarakat pada suatu tempat. Metode ini dilakukan dengan penelitian kualitatif fenomenologi. 


\section{DISKUSI DAN HASIL}

\section{Program}

Untuk menghadirkan hubungan timbal balik antargenerasi, dibutuhkan ruang bersama untuk mewadahi aktivitas. Hubungan timbal balik antargenerasi dapat tercipta melalui interaksi sosial. Aktivitas yang dapat menunjang interaksi sosial seperti olahraga tim, ruang untuk berkomunikasi, dan ruang bersama. Sehingga tercipta ruang untuk yang tua belajar dari yang muda, yang muda belajar dari yang tua. Bermain juga tidak terlepas dari pengelompokan umur. Apabila tidak dipisahkan, maka akan terjadi ketidakcocokan dalam bermain. Faktor keamanan juga perlu diperhatikan mengingat tingkat keamanan dari tiap segmen umur berbeda. Pengelompokan segmen umur bertujuan untuk menyesuaikan aktivitas permainan, keamanan, dan kemampuan bersosialisasi dalam bermain.



Gambar 2. Ilustrasi Tempat Bermain

Sumber: Penulis, 2020

Fasilitas Sosial berupa ruang ketiga memiliki fungsi dan aktivitas untuk menciptakan hubungan timbal balik antargenerasi melalui bermain. Selain melatih kemampuan otak, bermain dapat memenuhi gaya hidup dan sosial diluar rumah. Aktivitas berupa olahraga kelompok, ruang bersama, ruang bermain untuk tiap segmen umur, dan rooftop yang mewadahi untuk bersosialisasi.

\section{Analisa Tapak}

Untuk dapat membaca konteks tapak, dibutuhkannya analisa tapak. Mulai dari memperhatikan tapak dan sekitarnya untuk mendapatkan nilai positif dan negatif pada tapak. Analisa akan memberikan landasan mendesain dan menyikapi dalam bentuk sebuah rancangan. Sehingga rancangan dirasa tepat sasaran dan guna.

Akses

Tapak berada di Kelurahan Cipete Selatan, Kecamatan Cilandak, Jakarta Selatan. Tapak berada di Jalan Kemang Selatan XII E yang merupakan jalan lingkungan. Untuk mencapai tapak, harus melalui Jalan Puri Sakti yang merupakan jalan kolektor. Tapak juga merupakan akses untuk menuju ke Perkampungan Kota Kampung Manggar Kelape. 




Sumber: Penulis, 2020

\section{Vegetasi Sekitar Tapak}

Tapak tepat berada di selatan Kali Krukut. Dimana sekitaran Utara tapak terdapat area hijau yang luas. Memberikan potensi view dan point of interest dari pengolahan sebuah tapak. Ruang publik ini dapat menjadi katalis sekitar tapak untuk menanam banyak penghijauan.



Gambar 4. Vegetasi Sekitar

Sumber: Penulis, 2020

\section{Kampung Manggar Kelape}

Tapak adalah sebuah akses menuju ke perkampungan kota yang disebut Kampung Manggar Kelape. Kampung ini dikenal dengan Kampung Betawi yang menyelenggarakan Festival Palang Pintu setiap tahunnya. Perkampungan terasa lebih intim dibandingkan dengan perumahan menengah atas. Ruang bermain dapat menjadi ruang tengah antara perumahan kota dan kampung kota. 


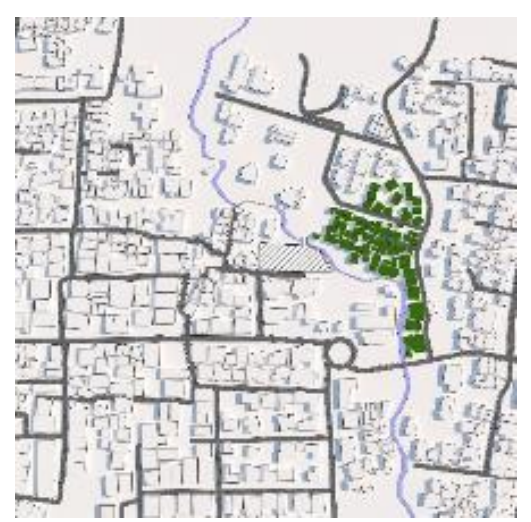

\section{Gambar 5. Kampung Manggar Kelape}

Sumber: Penulis, 2020

\section{Penduduk Berdasarkan Rumah}

Tapak berada diantara perkampungan kota, perumahan menengah keatas, dan komersil pada jalan arteri. Perbedaan pada kelas ekonomi menunjukan adanya kesenjangan sosial. Tapak ini memiliki peluang untuk menjadi titik temu dari kesenjangan sosial.

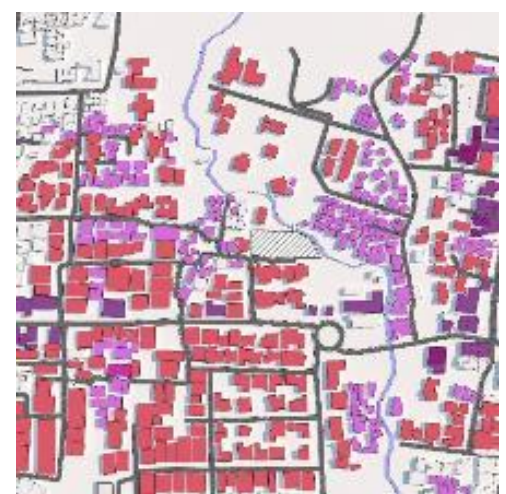

Gambar 6. Penduduk Berdasarkan Rumah

Sumber: Penulis, 2020

\section{Solid Void Tapak}

Solid Void pada tapak memberikan informasi pada bidang yang sudah dibangun dan yang belum terbangun. Informasi yang diberikan berupa ruang yang kosong (belum terbangun) dan ruang yang sudah terisi (sudah dibangun). Data ini memiliki peran dalam zoning massa bangunan dan area terbuka.



Gambar 7. Solid Void Tapak

Sumber: Penulis, 2020 


\section{Proses Gubahan}



Tapak dengan luas $2.530 \mathrm{~m} 2$ memiliki Koefisien Dasar Bangunan (KDB) sebesar 50\%, Koefisien Luas Bangunan (KLB) 2, Koefisien Dasar Hijau (KDH) 35\%, Ketinggian Bangunan (KB) 4, dan Koefisien Tapak Basemen (KTB) 50\%. Dari program diatas, tapak dibagi menjadi 6 bagian untuk memebuhi kebutuhan ruang dan aktivitas yang disebut bangsal. Lalu pembagian tapak berorientasi pada sungai karena memiliki potensi pada void dan view sehingga tapak menjadi lebih luas dan memiliki point of interest.

Akses menuju Kampung Manggar Kelape tetap dipertahankan dan terbuka untuk umum tanpa dibatasi waktu. Tapak menjadi penghubung antara perumahan kota dan perkampungan kota. Tapak memiliki 4 pintu untuk menghubungkan sisi utara kampung dan perumahan, sisi selatan pada tapak. Akses pintu masuk terdapat diujung tapak untuk memudahkan jangkauan pengguna sehingga langsung masuk menuju tapak. Lalu massa bangunan disesuaikan agar memberikan rongga yang berfungsi sebagai ruang terbuka. Fungsi ruang terbuka adalah untuk memberikan keleluasaan pada pengguna dan menjadi ruang untuk bersosialisasi.

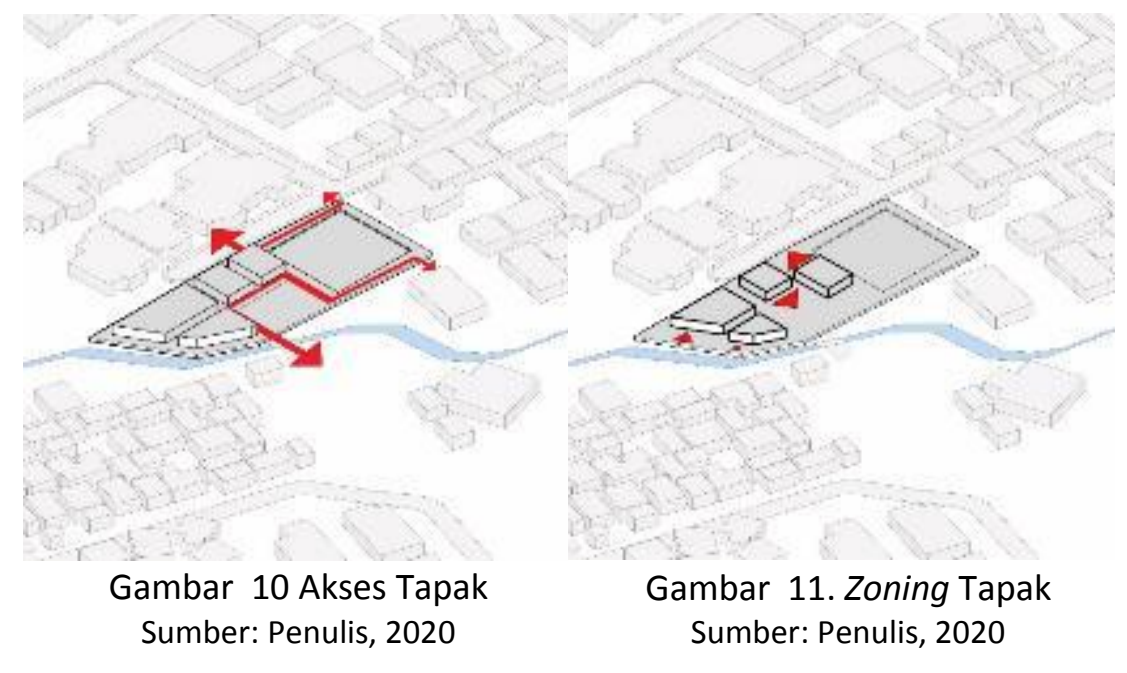

Lantai dasar terbuka sebagai ruang bersama, memberikan kebebasan untuk berinteraksi, bermain, dan bersosialisasi. Lantai satu berfungsi sebagai ruang bermain untuk tiap segmen umur yang dapat diubah menjadi ruang serbaguna ketika dibutuhkan. Lalu terdapat jembatan yang menghubungkan tiap bangsal. Bangsal terdiri dari 4 yaitu Bangsal Anak, Bangsal Remaja, Bangsal Dewasa, dan Bangsal Lansia sesuai dengan segmen umur. 


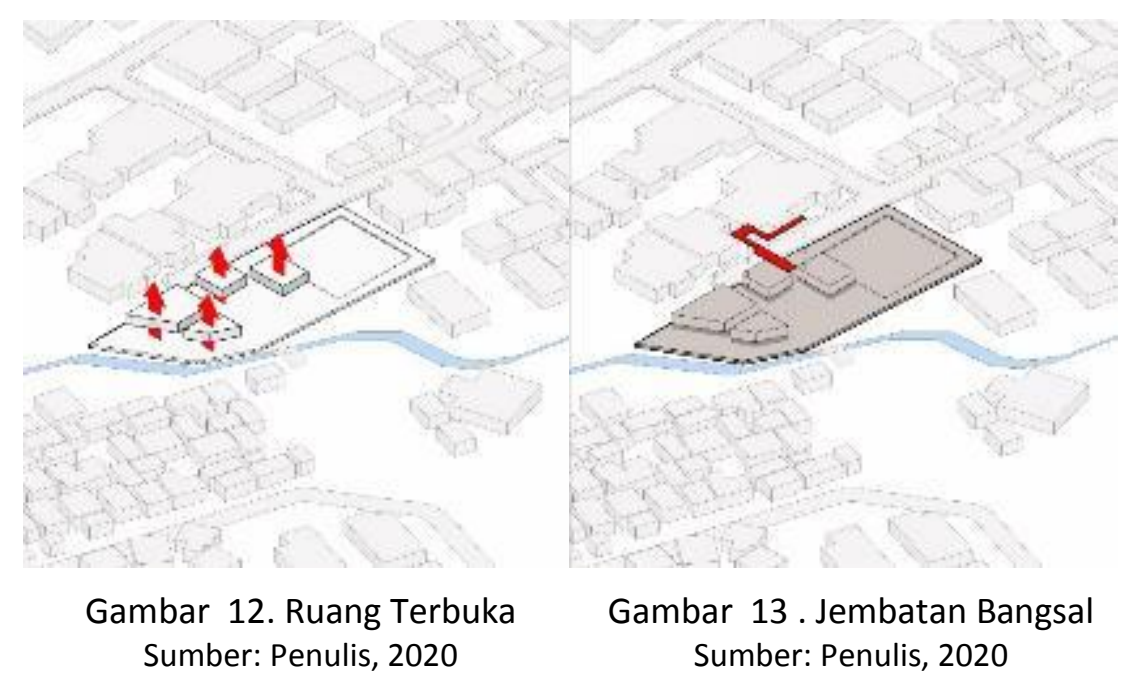

Lantai 2 berfungsi sebagi rooftop dan tempat untuk panel surya. Tiap bangsal memiliki rooftop untuk melakukan interaksi dan melihat pemandangan sekitar. Berikut adalah tahap akhir dari Ruang Bermain Cipete Selatan.

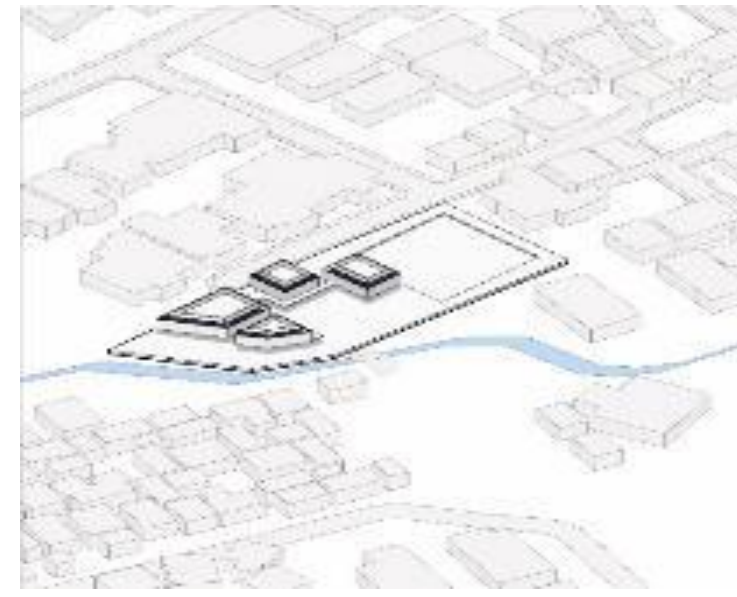

Gambar 14 . Rooftop \& Panel Surya Sumber: Penulis, 2020



Gambar 15. Ruang Bermain Cipete Selatan Sumber: Penulis, 2020

\section{Fasad}

Fasad adalah muka dari bangunan. Sebuah representasi guna dan citra. Eksperimen untuk mengangkat guna dan citra bangunan pada fasad merupakan sebuah tantangan. Implementasi fasad bangunan adalah hasil dari mendefinisikan fungsi bangunan. Open Architecture membawa sifat terbuka atau permeable. Sifat terbuka ada ketika berada diantara bidang masif yang terpisah. Biasanya karakter bangunan yang memberikan identitas tempat, menggunakan pola atau motif (Schulz, 1976). Mendefinisikan Open Architecture memberikan gambaran dari sebuah pola yang coba dihadirkan pada fasad. Kriteria Third Place salah satunya adalah memiliki fisik yang plain dan sederhana. Berdasarkan kriteria Third Place, penggunaan kulit bangunan dirasa tepat. Bangunan ditutup dengan selubung yaitu kulit bangunan agar terlihat plain dan sederhana. 


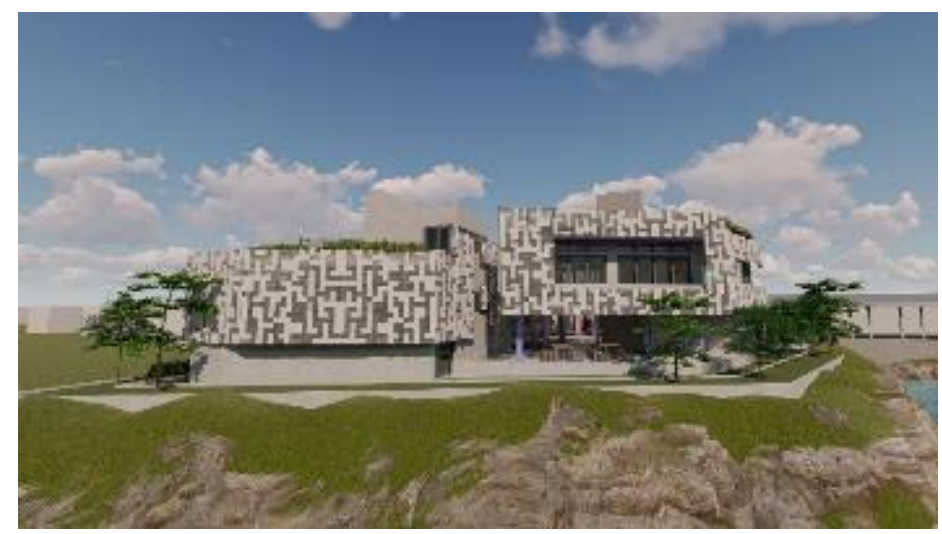

Gambar 16. Fasad Ruang Bermain Cipete Selatan

Sumber: Penulis, 2020

Perpaduan Third Place dan Open Architecture membawa pada hasil desain fasad bangunan. Material yang digunakan adalah besi perforasi untuk kulit bangunan yang dipadukan dengan Aluminium Composite Panel untuk pola fasad. Fungsi fasad adalah untuk menangkal cahaya matahari, memberikan pemandangan keluar bangunan, dan identitas. Proses penambahan dan pengurangan bidang fasad adalah untuk merespon cahaya matahari barat dan view keluar bangunan. Identitas fasad dihadirkan untuk memberikan perbedaan dari bangunan sekitar tapak yang didominasi oleh hunian.

\section{KESIMPULAN DAN SARAN \\ Kesimpulan}

Ruang publik memiliki peran yang penting dalam membentuk karakter kota. Kesenjangan sosial dapat dihilangkan dengan adanya ruang publik yang inklusif. Dimana masyarakat dapat beraktivitas dan bersosialisasi dengan masyarakat lainnya. Ruang publik dengan konsep Open Architecture dan Third Place mampu menciptakan ruang publik yang bermanfaat untuk penggunanya. Dengan teori arsitektur yang memiliki intensi untuk bermain dan berinteraksi diharapkan dapat menjadi ruang aktivitas yang bermanfaat untuk Masyarakat Cipete Selatan. Suasana yang coba diciptakan adalah hubungan timbal balik antargenerasi. Manfaatnya untuk usia yang lebih muda adalah melatih komunikasi, melatih daya nalar, dan berbagi budaya dan tradisi. Untuk usia yang lebih tua adalah memberikan semangat dan menjadi kesempatan untuk bernostalgia. Praktek ini tidak terlepas dari meningkatkan kemampuan bersosial dan tata krama dalam berinteraksi. Syarat utama menciptakan hubungan timbal balik membutuhkan ruang publik yang inklusif untuk semua umur. Untuk menarik tiap segmen umur dibutuhkan program yang mengikuti minat masing-masing segmen umur.

Berbagi ruang merupakan etika yang dipraktekan diluar ruang pertama. Bagi anak, ruang publik merupakan salah satu tempat untuk belajar berbagi ruang dalam melatih kemampuan sosial. Dengan ini, Ruang Bermain Cipete Selatan memberikan fasilitas berupa ruang bermain berdasarkan segmen umur agar dapat melatih atau mengembangkan kemampuan sosial bersama dengan segmen umur masing-masing. Ketika sudah memiliki kemampuan sosial dan terus berkembang, setiap segmen umur dapat berinteraksi atau berbagi pada ruang bersama yang direncanakan untuk menghadirkan suasana antargenerasi yang positif.

\section{Saran}

Pemikiran dan hasil karya tugas akhir penulis ini masih jauh dari kata sempurna. Karya aristektur merupakan hasil dari ide. Dalam aristektur, tidak ada karya yang sempurna melainkan tepat. Ketepatan dalam berarsitektur memberikan ruang untuk adanya penyempurnaan. Untuk itu, penulis sangat terbuka akan saran dan masukan dari pembaca. 


\section{REFERENSI}

Alexander, C., Ishikawa, S., Silverstein, M., Max, J., Fiksdahl-King, I., \& Angel, S. (1977). A Pattern Language. New York State Unites States of America.

Badan Pengembangan dan Pembinaan Bahasa. (2016, October 28). Tentang Kami: Badan Pengembangan dan Pembinaan Bahasa. Retrieved July 12, 2020, from KBBI Daring: https://kbbi.kemdikbud.go.id diakses

Halloran, J. (2018, April 5). About Us: Encourage Play. Retrieved July 11, 2020, from Encourage Play: https://www.encourageplay.com

Hughes, B. (2002). A Playworker's Taxonomy of Play Types. London: PlayLink.

Lefaivre, L., \& Doll. (2007). Ground-Up City Play as a Design Tool. Rotterdam: 010 Publishers.

Oldenburg, R. (1996, October 1). The Great Good Place. Cambridge Center, America.

Schulz, C. N. (1976). Genius Loci. New York: Rizzoli.

Sutanto, A. (2020, Januari 16). Architecture of the Third Place. Dipresentasikan pada kuliah umum. Universitas Tarumanagara. 
